\title{
The oldest African eucryptodiran turtle from the Cretaceous of Angola
}

Octávio Mateus, Louis Jacobs, Michael Polcyn, Anne S. Schulp, Diana Vineyard, André Buta Neto, and Miguel Telles Antunes

Acta Palaeontologica Polonica 54 (4), 2009: 581-588 doi: http://dx.doi.org/10.4202/app.2008.0063

A new Late Cretaceous turtle, Angolachelys mbaxi gen. et sp. nov., from the Turonian ( 90

Mya) of Angola, represents the oldest eucryptodire from Africa. Phylogenetic analysis

recovers Angolachelys mbaxi as the sister taxon of Sandownia harrisi from the Aptian of Isle of

Wight, England. An unnamed turtle from the Albian Glen Rose Formation of Texas (USA) and

the Kimmeridgian turtle Solnhofia parsonsi (Germany), are successively more

distant sister taxa. Bootstrap analysis suggests those four taxa together form a

previously unrecognized monophyletic clade of marine turtles, herein named

Angolachelonia clade nov., supported by the following synapomorphies:

mandibular articulation of quadrate aligned with or posterior to the occiput, and

basisphenoid not visible or visibility greatly reduced in ventral view. Basal

eucryptodires and angolachelonians originated in the northern hemisphere, thus Angolachelys represents

one of the first marine amniote lineages to have invaded the South Atlantic after separation of Africa and South America.

Key words: Chelonia, Eucryptodira, paleobiogeography, Cretaceous, Angola.

Octávio Mateus [omateus@fct.unl.pt], Departamento de Ciências da Terra

(CICEGe- FCT), Universidade Nova de Lisboa, Lisbon, and Museu da Lourinhã,

Rua João Luis de Moura, 2530-157 Lourinhã, Portugal; Louis Jacobs [jacobs@ mail.smu.edu

], Michael Polcyn [mpolcyn@mail.smu.edu], and Diana Vineyard [vineyard@mail.smu.edu

], Roy M. Huffington Department of Earth Sciences, Southern Methodist

University, Dallas, Texas 75275 USA; Anne S. Schulp [anne.schulp@ maastricht.nl

], Natuurhistorisch Museum Maastricht, De Bosquetplein 6-7, NL-6211 KJ

Maastricht, The Netherlands; André Buta Neto [anbuneto@ hotmail.com

], Departamento de Geologia, Universidade Agostinho Neto, Luanda,

Angola; Miguel Telles Antunes [migueltellesantunes@gmail.com], Academia de Ciências de Lisboa, Rua da Academia das Ciências, 19. 1242-122 Lisboa. 
This is an open-access article distributed under the terms of the Creative Commons

Attribution License (for details please see creativecommons.org), which permits unrestricted use, distribution, and reproduction in any medium, provided the original author and source are credited.

FaF 